\title{
Jurassic planktic foraminifera from the Polish Basin
}

\author{
Maria Gajewska $^{1}$, Zofia Dubicka ${ }^{1}$, and Malcolm B. Hart ${ }^{2}$ \\ ${ }^{1}$ University of Warsaw, Faculty of Geology, al. Żwirki i Wigury 93, 02-089 Warsaw, Poland \\ ${ }^{2}$ School of Geography, Earth \& Environmental Sciences, University of Plymouth, Drake Circus, \\ Plymouth PL4 8AA, UK \\ Correspondence: Zofia Dubicka (z.dubicka@uw.edu.pl)
}

Received: 1 June 2020 - Revised: 30 October 2020 - Accepted: 22 November 2020 - Published: 27 January 2021

\begin{abstract}
Jurassic (Bathonian-Oxfordian) planktic foraminifera from the epicontinental strata of the Polish Basin have been investigated. The palaeoecology, palaeobiogeography, and biostratigraphical potential of the recorded taxa are discussed. Four species are recorded: Conoglobigerina helvetojurassica (Haeusler, 1881), Globuligerina balakhmatovae (Morozova, 1961), G. bathoniana (Pazdrowa, 1969), and G. oxfordiana (Grigelis, 1958). This assemblage is probably the most diverse of those described to date from the epicontinental areas of Europe. The recorded taxa are thought to represent three different ecological morphotypes. The clear relationship between transgressive-regressive facies and the palaeobiogeography of the recorded planktic foraminifera indicates a morphotype-related depth-distribution pattern in which small, simple, globular-chambered morphotypes occupied shallow waters whereas slightly larger, more complex forms, or those with hemispherical chambers, inhabited deeper and more open-water environments.
\end{abstract}

\section{Introduction}

Foraminifera constitute an unique group of marine protists that are used extensively as biostratigraphical and palaeoenvironmental proxies in the Earth sciences. Planktic foraminifera are especially useful due to their very wide, near-global, distribution (Masters, 1977; Hart, 1999; Premoli Silva and Sliter, 1999; Gradstein et al., 2017a). The adaptation to a planktic lifestyle took place relatively late in the history of the foraminifera, as benthic forms may have appeared in the Neoproterozoic (Pawlowski et al., 2003). It is suggested that planktic taxa appeared in the late Early Jurassic (Toarcian, $\sim 180 \mathrm{Ma}$ ) following work by Wernli (1988, 1995), Simmons et al. (1997), Hart et al. (2003), Hudson et al. (2009), Leckie (2009), Gradstein (2017), and Gradstein et al. $(2017 \mathrm{a}, \mathrm{b})$. The origin of planktic foraminifera, from benthic ancestors, is a key question in the evolutionary history of the foraminifera and in biological oceanography in general.

Shelf environments, probably close to continental margins, were the preferred habitat for the first appearance of primitive planktic foraminifera (Gordon, 1970; Gradstein et al., 2017b). Because the area of extra-Carpathian Poland was covered during the Middle and Late Jurassic by a relatively shallow, epicontinental, sea that extended from the northern part of the Tethys (northern Tethyan shelf), it appears to be a favourable ecological niche for planktic foraminifera and contains an important fossil record (Olszewska and Wieczorek, 1988; Wierzbowski et al., 2009) in both the deeper waters of the Inner and Outer Carpathians and the shallower waters of the foreland region of the Polish Basin (north of Kraków). What is more, the rather low degree of diagenetic modification, and the high content of clay minerals in the sediments of the Polish Basin, enabled the preservation of aragonite foraminiferal tests. These mudstones also allow specimens to be extracted with little difficulty. This procedure is essential for morphological analysis and taxonomic identification of the planktic taxa, as compared to the thin section studies of Görög (1994) and Wernli and Görög (2000). Wernli and Görög (1999) also resorted to acid reductions of limestones from Hungary in order to study their material in 3-D. Despite these uniquely favourable research conditions in the Polish Basin, Jurassic planktic foraminifera have been described by very few authors, mostly during the 1960s and 1970s (Bielecka, 1960; Bielecka and Styk, 1967; Pazdrowa, 1969; Fuchs, 1973; Olszewska and Wieczorek, 1988). The aim of our research was to summarize the present 
knowledge of the planktic foraminifera from the studied area as well as to analyse newly collected material. Therefore, our research objectives were to understand the taxonomy, evolution, and palaeoecology of the Jurassic planktic foraminifera and demonstrate their utility in Late Jurassic stratigraphy and palaeoenvironmental interpretations.

Before discussion of our procedures it is important to record that both Oberhauser (1960) and Fuchs (1967, 1970) were interested in the origins of the planktic foraminifera and, in major investigations of Triassic and Lower Jurassic successions in Austria and northern Italy, erected a suite of both genera and species that were based on washed residues that provided 3-D material. Malcolm B. Hart, with the assistance of Holger Gebhardt, studied the Oberhauser and Fuchs material in the collections of the Geological Survey of Austria (including all of the type slides of the new taxa). This investigation concluded that, almost certainly, none of the taxa were planktic, and this was the same conclusion as that of Simmons et al. (1997). There are some taxa in the collection (Oberhauserella and Praegubkinella) that look to be very close to developing a planktic morphotype but may still be benthic in palaeoecology. Also in the collections are the taxa erected by Fuchs (1973) based on material collected by Manfred E. Schmid (Geological Survey of Austria) during the 10th European Micropalaeontological Colloquium. These meetings were held on a regular basis for many years and allowed "invited" geoscientists to visit key localities in Europe and collect, under local guidance, material for their institutions. The samples for the study by Fuchs (1973) appear to have come from the upper Callovian and lowermost Oxfordian of the "Kalksteinbruch von Wiek" near Ogrodzieniec. Both of the samples used by Fuchs (1973) - from beds 21 and 26 - are recorded as coming from the glauconitic marls that are present at the Callovian-Oxfordian boundary. In his paper, Fuchs $(1973$, p. 462, 474) describes his specimens as being "glauconitkern", an internal cast composed of the Fe-rich clay mineral glauconite. This preservation was also noted by Loeblich and Tappan (1987) in their discussion of some of Fuchs' new genera. Based on glauconitic steinkerns and with no test material or apertures preserved, all of the new taxa erected by Fuchs (1973) are, almost certainly, invalid

The full significance of this style of preservation only became apparent when Plymouth-based PhD student Wendy Hudson attended the 7th International Congree on the Jurassic System in September 2006. The field excursion guidebook (Matyja and Wierzbowski, 2006) illustrates (op. cit., Fig. B1.8) an excavated section in the Ogrodzieniec Quarry in which the Ogrodzieniec Glauconitic Marls Formation (of latest Callovian and earliest Oxfordian age) is illustrated. Samples from this temporary exposure were collected, processed in Plymouth, and used by Hudson (2007) in her $\mathrm{PhD}$ thesis. Both samples contain almost no residue (when washed on a $63 \mu \mathrm{m}$ sieve) aside from grains of glauconite, a very high proportion of which are the internal casts of both

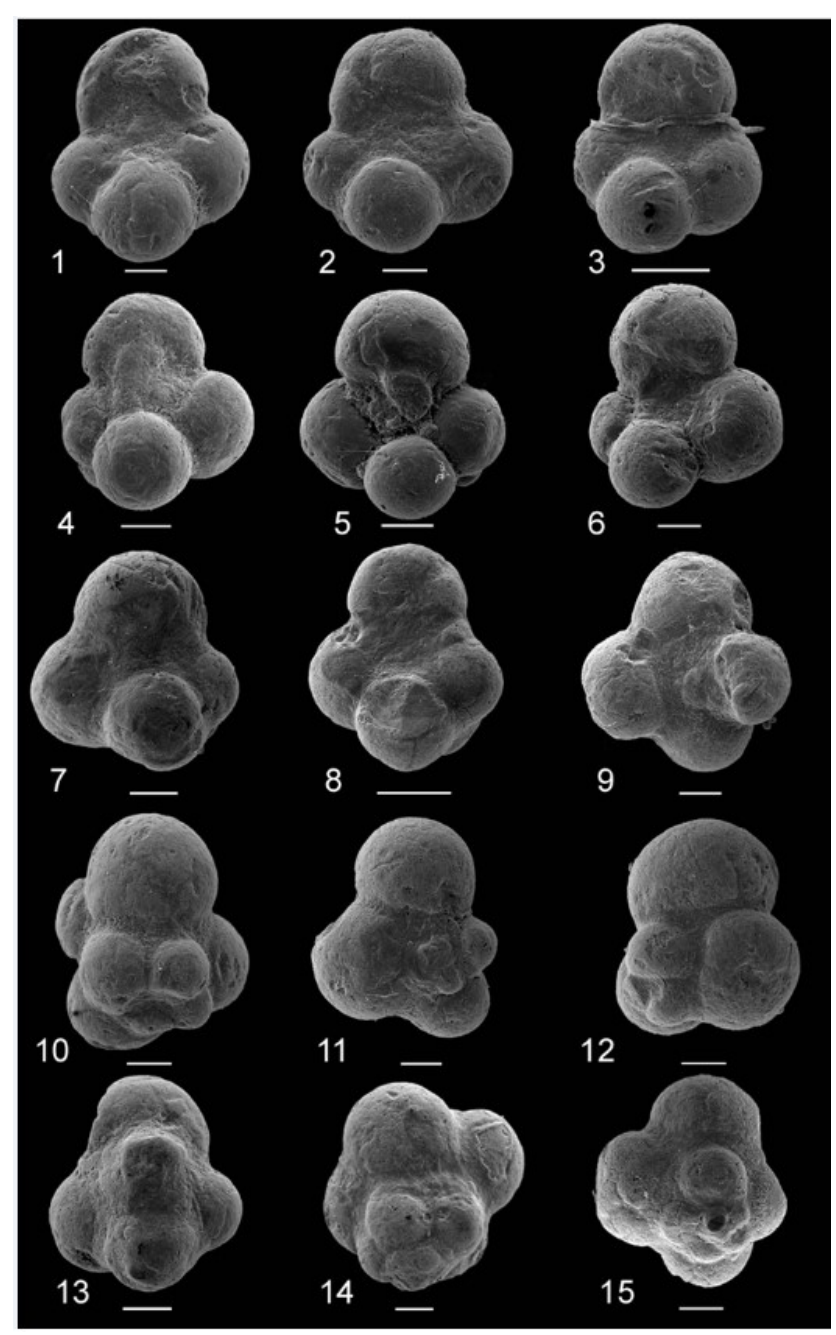

Figure 1. Glauconitic steinkerns of Globuligerina sp. cf. G. oxfordiana from the Callovian-Oxfordian boundary section, Ogrodzieniec, Poland. All scale bars represent $50 \mu$ m except 3 and 8 in which scale bars are $100 \mu \mathrm{m}$.

benthic - but mainly planktic - foraminifera. A study of the Fuchs (1973) collection in Vienna confirmed that the material is probably identical and that the samples collected by Manfred E. Schmid are from the same formation.

This comparison did resolve one problem with the illustrations displayed in Fuchs (1973). Despite being a good likeness of the material, Malcolm B. Hart could not understand the "double" lines in many of the drawings which, in places, are almost suggestive of marginal keels. Many of the specimens in our material have a different colour (dark green) of glauconite within the chambers and a slightly paler green where septa or chamber edges would have been located.

On a return visit to the Ogrodzieniec Quarry in 2011, with Jarosław Tyszka and Eiichi Setoyama, the temporary exposure created for the Jurassic symposium had been infilled and the Glauconitic Marls Formation was only exposed in 


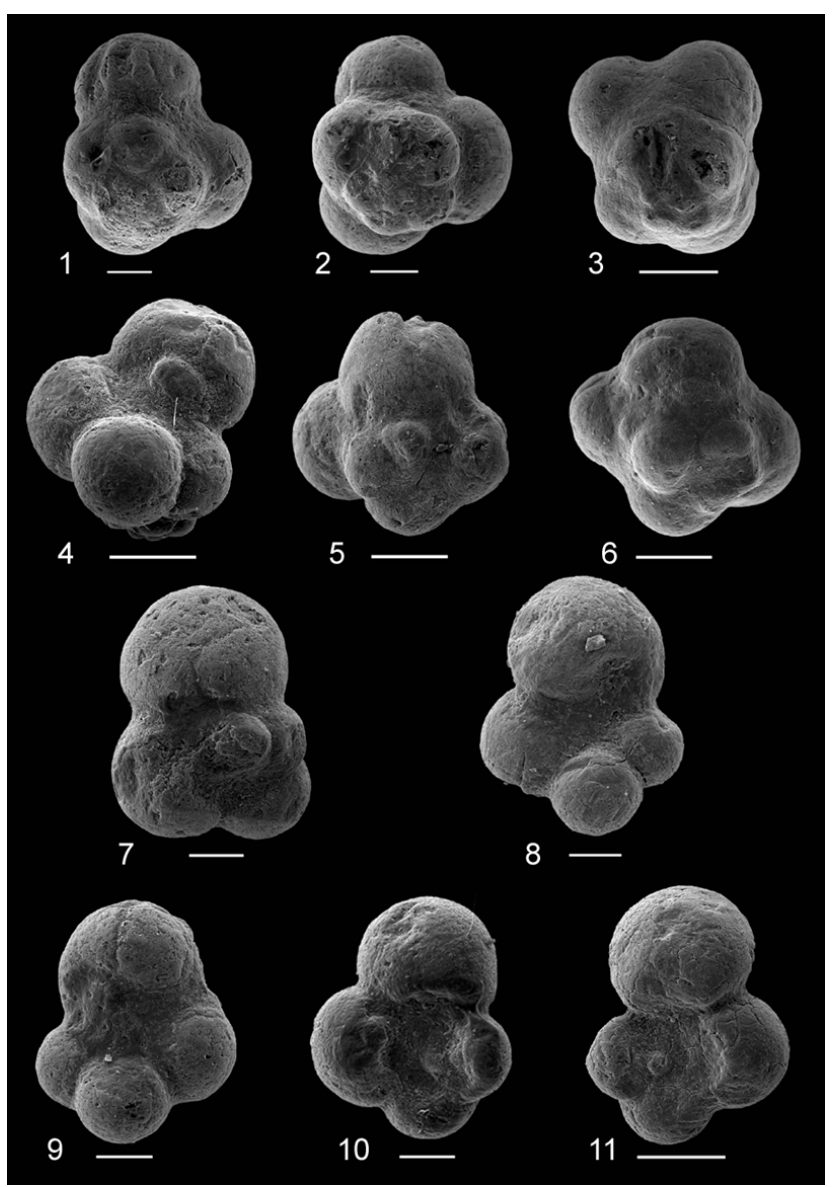

Figure 2. Glauconitic steinkerns of (1-8) Globuligerina sp. cf. G. oxfordiana and (9-11) Conoglobigerina helvetojurassica from the Callovian-Oxfordian boundary section, Ogrodzieniec, Poland. All scale bars represent $50 \mu$ m except 3, 4, 5, 6, and 11 in which scale bars are $100 \mu \mathrm{m}$.

a track-side area $\left(50^{\circ} 46^{\prime} 46.5^{\prime \prime} \mathrm{N}, 19^{\circ} 51^{\prime} 86.2^{\prime \prime} \mathrm{E}\right)$ with limited stratigraphical thickness visible. Samples from this very small section yielded the same type of residue with only glauconitic steinkerns present when washed on a $63 \mu \mathrm{m}$ sieve. This material is exceptionally rich in planktic foraminifera with benthic foraminifera represented by only $10 \%-15 \%$ of the assemblage (Figs. 1, 2).

\section{Material and methods}

In total, 43 samples were examined for foraminiferal studies. The samples came from the Wrzosowa (6), Kawodrza (3), Stare Gliny (19), Ogrodzieniec (4), Gnaszyn (7), Bolęcin (1), Czatkowice (1), Gorenice (1), and Podłęże (1) quarries located in the Polish Jura (Fig. 3), which, combined, expose strata from the Morrisi Zone (middle Bathonian, Middle Jurassic) to the Bifurcatus Zone (upper Oxfordian, Upper Jurassic). We have sampled all available stratigraphical divisions (ammonite zones). Specifi-

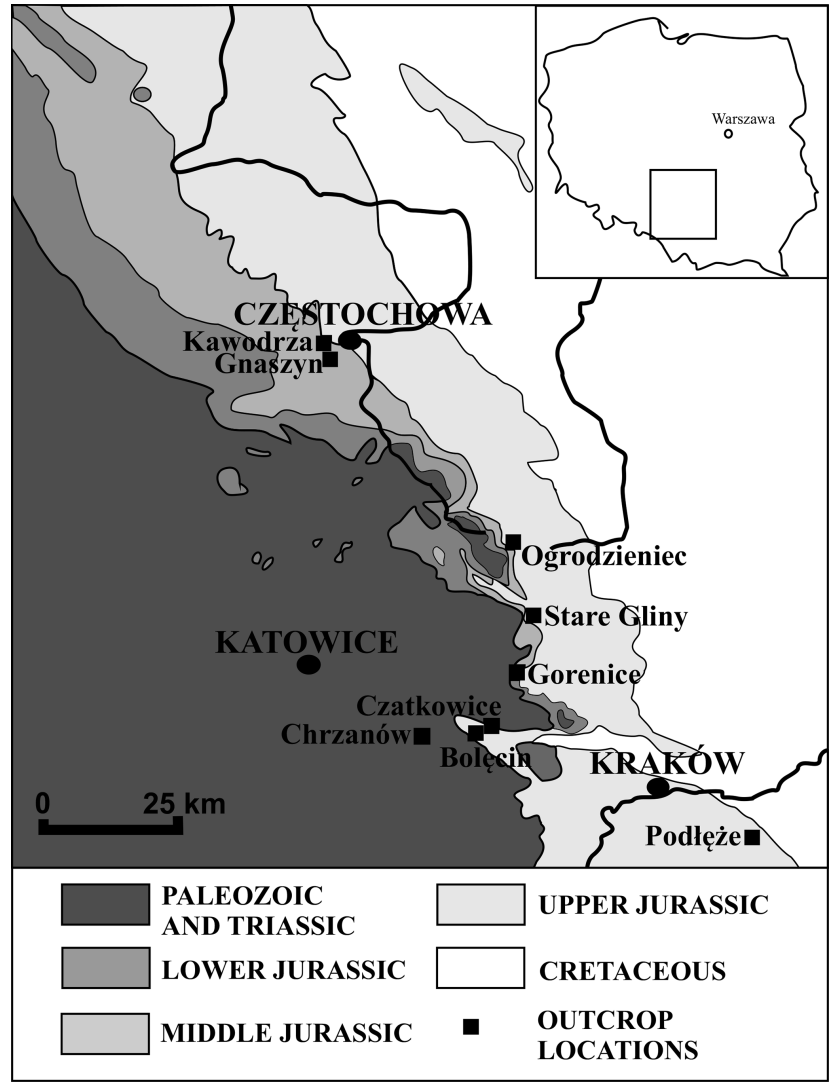

Figure 3. Geological pre-Cenozoic sketch map of the Polish Jura and adjoining areas (after Wierzbowski et al., 2009) showing the location of sections studied and previously described in the literature: Chrzanów (Bielecka, 1960), Ogrodzieniec (Bielecka and Styk, 1967; Pazdrowa, 1969), and Gnaszyn (Smoleń, 2012).

cally, the Morrisi Zone (middle Bathonian) was sampled in the Kawodrza $\left(50^{\circ} 48^{\prime} 09.8^{\prime \prime} \mathrm{N}, 19^{\circ} 04^{\prime} 01.2^{\prime \prime} \mathrm{E}\right)$ and Gnaszyn $\left(50^{\circ} 48^{\prime} 05.5^{\prime \prime} \mathrm{N}, 19^{\circ} 02^{\prime} 42.3^{\prime \prime} \mathrm{E}\right)$ clay pits. These locations display a rather homogenous succession of black clays, with the sporadic occurrence of siderite nodule horizons (Matyja and Wierzbowski, 2003; Matyja et al., 2006b; Leonowicz, 2012; Parent and Zatoń, 2016).

Upper Bathonian and lower to middle and middle Callovian deposits that developed as clays and glauconitic marls respectively were sampled in Ogrodzieniec $\left(50^{\circ} 27^{\prime} 54.6^{\prime \prime} \mathrm{N}\right.$, $19^{\circ} 31^{\prime} 17.2^{\prime \prime} \mathrm{E}$ ) by Dembicz in 2006 (Dembicz and Praszkier, 2003; Matyja and Głowniak, 2003; Barski et al., 2004; Dembicz et al., 2006; Wierzbowski et al., 2009; Leonowicz, 2013). The Glauconitic Marls Formation (uppermost Callovian to lowermost Oxfordian) was, as reported above, sampled by Hudson in 2006 and by Malcolm B. Hart in 2011. At the present time, the lower part of the outcrop is unavailable.

An incomplete succession from the Jason Zone (middle Callovian) to the Bifurcatus Zone (middle to upper Oxfordian) was sampled exclusively in the Stare Gliny Quarry $\left(50^{\circ} 21^{\prime} 00.8^{\prime \prime} \mathrm{N}, 19^{\circ} 35^{\prime} 29.2^{\prime \prime} \mathrm{E}\right.$ ) (Wierzbowski et al., 2009, 
2021). This important Jurassic section is about $21 \mathrm{~m}$ thick and includes middle to upper Callovian marl-limestone rhythmites (10 samples; $9 \mathrm{~m}$ ) and lower to upper Oxfordian clay strata (9 samples; $12 \mathrm{~m}$ ).

Jurassic strata in the Wrzosowa Quarry $\left(50^{\circ} 45^{\prime} 25.4^{\prime \prime} \mathrm{N}\right.$, $\left.19^{\circ} 08^{\prime} 51.9^{\prime \prime} \mathrm{E}\right)$ are represented by a succession, approximately $5 \mathrm{~m}$ thick, of Cordatum Zone (lower Oxfordian) marl-limestone rhythmites with the dominant limestone of the Jasna Góra beds, yielding numerous sponges, belemnites, ammonites, and brachiopods (Trammer, 1985; Matyja et al., 2006a; Wierzbowski et al., 2009; Głowniak, 2012). Some isolated samples of Callovian and Oxfordian strata were additionally collected from little-known sections such as Bolęcin (lower Callovian) (Różycki, 1953), Czatkowice (Lamberti Zone, upper Callovian) (Dayczak-Calikowska and Kopik, 1973a; Salata, 2013), Gorenice (lower Oxfordian) (Różycki, 1953), and Podłęże (middle Oxfordian) (Giżejewska and Wieczorek, 1977; Jurkowska and Kołodziej, 2013).

All of the collected samples are characterized by high clay content, which provides excellent conditions for fossil preservation, enabling the acquisition of isolated free specimens from the sediments (Hart et al., 2019). The use of 3-D specimens instead of thin sections (see the work of Hudson et al., 2009, on material from the Inner Carpathians) afforded us improved data for detailed morphological analysis. Selectively collected clay-rich samples were disintegrated using Glauber's salt $\left(\mathrm{Na}_{2} \mathrm{SO}_{4} \times 10 \mathrm{H}_{2} \mathrm{O}\right)$ or detergent (Witwicka et al., 1958). The material was then washed in an ultrasonic cleaner and sieved using two sieves: $0.071 \mathrm{~mm}$ (lower) and $0.6 \mathrm{~mm}$ (upper). Samples that required additional cleaning were treated with liquid nitrogen (Remin et al., 2012). Foraminifera were manually picked from the residue and studied with the use of a Nikon SMZ18 stereoscopic microscope. Taxonomic observations and images were generated using a Zeiss Sigma VP scanning electron microscope at the Faculty of Geology, University of Warsaw.

\section{Results}

In general, planktic foraminifera in the samples were abundant, if not very numerous, and variably preserved. In all of the samples from Wrzosowa and some from Gnaszyn (G1252, G1264, G1318), Kawodrza (K1), Ogrodzieniec (O1, O2, O3), and Stare Gliny (ST6B, ST6F, ST6H, ST18, ST0, ST60, ST560), planktic forms were absent. The scarcity of foraminifera was almost certainly caused by the dissolution of their aragonitic tests, as all of the aragonitic benthic foraminifera had also been lost and the foraminiferal assemblages were represented only by benthic foraminifera with calcitic wall structures. Planktic foraminifera were recorded in the other studied samples, although their state of preservation was variable. Rather poorly preserved specimens with obscure morphological features, such as ornamentation or apertures (some of the specimens were preserved as glauconitic internal moulds, as described above in material from Ogrodzieniec) were collected from the Callovian of Stare Gliny (samples 2, 4, 16), Czatkowice, Gorenice, and Podłęże, whereas very well-preserved specimens were obtained mostly from samples that came from Gnaszyn (sample 1330), Kawodrza (samples 2, 3), and Stare Gliny (samples 140, 320, 500).

In our material, four species from two genera were recorded: Conoglobigerina helvetojurassica (Haeusler, 1881), Globuligerina balakhmatovae (Morozova, 1961), Globuligerina bathoniana (Pazdrowa, 1969), and Globuligerina oxfordiana (Grigelis, 1958) (Fig. 4). C. helvetojurassica is characterized by a low to medium-high trochospiral large test; the mean diameter measured on 10 randomly selected specimens was $260 \mu \mathrm{m}$. The almost spherical chambers are much larger in the last whorl than those in the previous whorl, and they sit close to each other. Well-preserved pseudomuricae are visible on the surface of the test. G. balakhmatovae has a much smaller and low trochospiral test with oval, almost petaloid chambers. The chamber flattening, commonly observed in the studied specimens, is apparently a primary feature and is not produced during taphonomy. The main diagnostic features of $G$. bathoniana are a high trochospiral test, spherical chambers, and a test surface almost covered by pustulose ornamentation. The mean diameter of $G$. bathoniana, measured on 10 randomly selected specimens, was $160 \mu \mathrm{m}$. Similarly, G. oxfordiana is characterized by pustulose ornamentation. The coiling of the test is, however, that of a relatively low trochospiral. The last chamber is significantly larger than earlier ones and is often more elongated. The mean size of 10 randomly selected specimens of $G$. oxfordiana was $150 \mu \mathrm{m}$.

The most common taxa in our material were $G$. bathoniana and $G$. oxfordiana. G. bathoniana was the most numerous in Bathonian strata, especially in the Morrisi Zone (middle Bathonian) of Gnaszyn and Kawodrza, and in the Callovian and Oxfordian sediments of Bolęcin, Czatkowice, Ogrodzieniec, Podłęże, and Stare Gliny. A relatively similar stratigraphical distribution was observed for $G$. oxfordiana, which was a dominant component of the Czatkowice, Podłęże, and Stare Gliny assemblages but rare in the Bathonian samples from Gnaszyn and Kawodrza. Specimens of $C$. helvetojurassica were recorded exclusively in the upper Oxfordian (Bifurcatus Zone) sediments from Stare Gliny (samples 140, 200, 380). Well-preserved specimens retained the characteristic pseudomuricae ornamentation, which is a diagnostic feature of the genus Conoglobigerina (Simmons et al., 1997; Gradstein et al., 2017a). Specimens of G. balakhmatovae were found in four samples from Kawodrza (Morrisi Zone, middle Bathonian) and from the Bifurcatus Zone (of Stare Gliny (upper Oxfordian) samples 140, 320, 380). No hemispherical forms were recorded from any Callovian (Jason-Lamberti zone) sediments. 


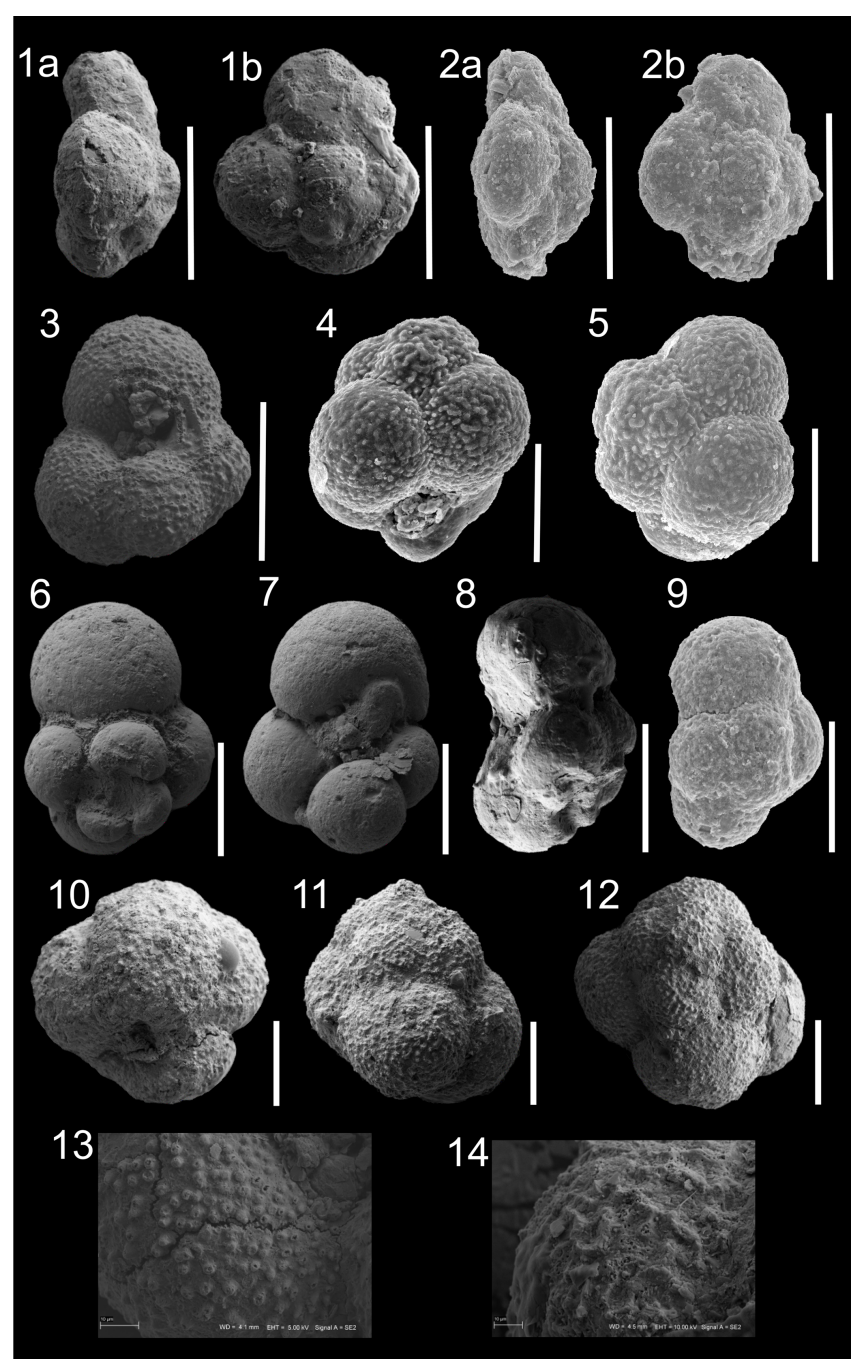

Figure 4. SEM images of studied planktic foraminifera. Globuligerina balakhmatovae (Morozova, 1961) specimens: (1a-b) Stare Gliny, sample 140, MWGUW ZI/67/MG4.65 and (2a-b) Stare Gliny, sample 140 MWGUW ZI/67/ZD64ST14. Globuligerina bathoniana (Pazdrowa, 1969) specimens: (3, 4) Gnaszyn, sample 1324, MWGUW ZI/67/MG1.01 and (5) Stare Gliny, sample 140, MWGUW ZI/67/ZD64ST02. Globuligerina oxfordiana (Grigelis, 1958) specimens: (6) Podłęże, sample 1, MWGUW ZI/67/MG1.42; (7) Podłęże, sample 1, MWGUW ZI/67/MG1.20; (8) Stare Gliny, sample 6, MWGUW ZI/67/MG4.62; and (9) Stare Gliny, sample 140, MWGUW ZI/67/ZD64ST03. Conoglobigerina helvetojurassica (Haeusler, 1881) specimens: (10) Stare Gliny, sample 380, MWGUW ZI/67/MG3.12; (11) Stare Gliny, sample 120, MWGUW ZI/67/MG4.57; (12) Stare Gliny, sample 140, MWGUW ZI/67/MG4.07. Characteristic wall ornamentation (13-14) of genus: (13) Globuligerina, Gnaszyn, sample 1312, MWGUW ZI/67/MG1.02 and (14) Conoglobigerina, Stare Gliny, sample 140, MWGUW ZI/67/MG4.49. All scale bars represent $100 \mu \mathrm{m}$.

\section{Discussion}

\subsection{Species variability of Jurassic planktonic foraminifera in extra-Carpathian Poland}

Beginning in the second half of the 20th century, Jurassic planktic foraminifera have been investigated worldwide (Gradstein et al., 2017a), although few investigations have been undertaken in extra-Carpathian Poland. The first records derive from the Polish Jura where, in the late 1960s, Globuligerina sp. cf. G. oxfordiana and Globuligerina sp. cf. G. helvetojurassica (Bielecka and Styk, 1967) were found in middle-upper Callovian (Jason-Lamberti zones) and Mariae Zone (lower Oxfordian) strata of Ogrodzieniec. In 1969, Olga Pazdrowa described G. bathoniana from the Morrisi Zone (middle Bathonian) exposed in this quarry. It should be remembered, however, that her work was carried out in 1959 as that is the date written (by her) on the slides in the collections of the institute in Kraków. Several years later, Fuchs (1973) published his description of planktic foraminifera from the Polish Jura, identifying many new species. As all of this material is illustrated by line drawings of moulds, without original test walls, ornamentation, and apertures, none of these new taxa are valid (Loeblich and Tappan, 1987; Hudson, 2009; Gradstein et al., 2017a); see earlier discussion.

Subsequently, several sites from extra-Carpathian Poland were studied in terms of Jurassic planktic foraminifera (Kraców region, by Olszewska and Wieczorek, 1988; Ogrodzieniec, by Hudson, 2009, and Hart et al., 2012; and Gnaszyn, by von Hillebrandt, 2012, Smoleń, 2012, and Kendall et al., 2020). Moreover, planktic foraminifera were recorded in microfossil assemblages from boreholes in northern Poland (Chrzanów, by Bielecka, 1960; Kcynia, by Bielecka and Styk, 1964; Pasłęk, by Bielecka and Styk, 1966; Bartoszyce, by Bielecka and Styk, 1966, and Bielecka, 1974; Grzybnica, by Bielecka and Styk, 1981; and Wolin, by Bielecka and Styk, 1981) where, apart from G. bathoniana from Wolin (Fig. 5), G. oxfordiana was the only recorded planktic taxon.

To summarize, planktic foraminifera from extraCarpathian Poland are rather scarce and require additional investigation. In fact, to date, only two species of planktic foraminifera, G. bathoniana and G. oxfordiana, have been described with certainly from this region. It is worth mentioning that Bielecka and Styk $(1967,1981)$ recorded C. helvetojurassica in this area of Poland, although it is clearly indicated in their papers that this record is uncertain. There is only one very poor illustration of this species included in the work of Bielecka and Styk (1981), and this is probably inadequate for a reliable taxonomic identification.

G. oxfordiana is commonly regarded as a cosmopolitan Jurassic planktic form (Hudson et al., 2009), but this is probably the result of many authors naming any mid-Jurassic planktic form as this species. The newly studied Oxfordian 


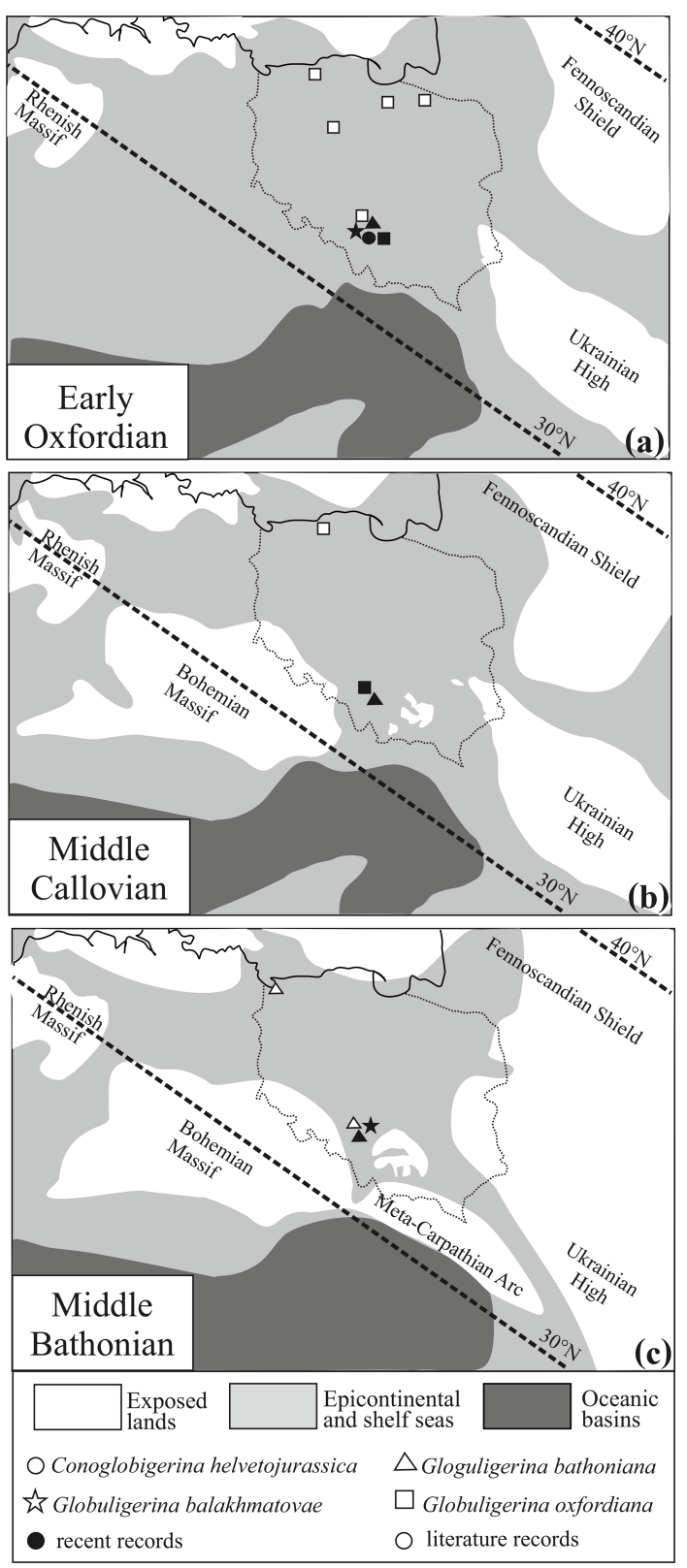

Figure 5. Palaeogeographical maps of the (a) middle Oxfordian, (b) middle Callovian, and (c) middle Bathonian of central Europe, with the distribution of planktonic foraminifera based on data in the subject literature (Bielecka, 1960, 1974; Bielecka and Styk, 1964, 1966, 1981) and recent studies.

assemblage from Stare Gliny is quite species-rich and probably one of the most diverse in the previously described area of epicontinental extra-Carpathian Poland and Europe in general. In this regard it is similar to the rather diverse assemblage seen as glauconitic steinkerns in the material from Ogrodzieniec described here. Specifically, this assemblage is composed of common G. bathoniana and G. oxfordiana but also includes the typical Tethyan $C$. helvetojurassica and G. balakhmatovae. These four taxa represent three different morphotypes: a small globular-chambered morphotype, represented by $G$. bathoniana and G. oxfordiana; the hemispherically chambered G. balakhmatovae; and the often larger and more complex $C$. helvetojurassica.

\subsection{Biostratigraphical remarks}

Gradstein et al. (2017a, b) show that the rate of speciation and evolutionary diversification of the first planktonic foraminifera was rather slow, confirming earlier suggestions by Simmons et al. (1997), Premoli Silva and Sliter (1999), Hart (1999), and Hart et al. (2002). Consequently, even the later Jurassic forms were characterized by a low level of morphological and taxonomic variability, which is, unfortunately, a serious disadvantage for stratigraphical studies. Additionally, the low preservation potential of the aragonitic tests of Jurassic planktic foraminifera very often results in their poor preservation or complete absence from the fossil record.

Not many species of Jurassic foraminifera are unquestionably considered as planktic. Gradstein et al. (2017a) described only 10 different species: Globuligerina dagestanica (Morozova), G. avariformis (Kasimova), G. balakhmatovae (Morozova), G. oxfordiana (Grigelis), G. bathoniana (Pazdrowa), G. jurassica (Hofman), G. oxfordiana (Grigelis) calloviensis Kuznetsova, G. tojeiraensis Gradstein, Conoglobigerina helvetojurassica (Haeusler), C. grigelisi Gradstein, and $C$. gulekhensis (Gorbachik and Poroshina). Recently, however, Apthorpe (2020) described three new planktic taxa: Globuligerina bathoniana australiana n. ssp., Globuligerina altissapertura $\mathrm{n}$. sp., and Mermaidogerina loopae $\mathrm{n}$. gen. n. sp. from the Bajocian of the southern Tethys (northwest Australia). These records, from dredge samples, lack precise dating, as the Jurassic material is entombed in Pleistocene sediments, but the occurrence - so far away from the otherwise European and North Atlantic Ocean locations creates problems for palaeogeographical reconstructions (see Hudson et al., 2009). This assemblage is, perhaps, more reminiscent of the Bathonian-Oxfordian interval than the Bajocian.

This rather low level of taxonomic diversity, the scattered occurrence and rather poor taphonomic potential of Jurassic planktics, and the lack of extensive sampling have resulted in a rather low level of resolution for standard biostratigraphical zonation (see Ogg et al., 2016). The most recent and exhaustive zonation of Jurassic planktonic foraminifera presented by Gradstein et al. (2017b) includes six zones (from J1 to J6). Unfortunately, the total ranges of specific zones have been established only tentatively and are still uncertain; no links to ammonite zones have been assigned. Nonetheless, Jurassic planktic foraminifera possess significant interregional correlative potential, as described from a wide palaeogeographical area including the eastern part of North America, Europe, the North Atlantic Ocean, the Gulf of Mexico, North Africa, the Middle East, and Australia. Additional investigations are, 
therefore, definitely needed in order to create a robust biostratigraphical zonation correlated with other groups of index fossils (especially calcareous nannofossils and ammonites).

The stratigraphical distribution of the studied taxa from the Polish Basin closely matches the biostratigraphical scheme of Gradstein et al. (2017b). In the studied area, the earliest forms recorded are G. bathoniana and G. balakhmatovae, which occurred in the Morrisi Zone (middle Bathonian) of Gnaszyn (see also Pazdrowa, 1969; Bielecka and Styk, 1981; Hart et al., 2012; Smoleń, 2012; Kendall et al., 2020) and Kawodrza (Fig. 6). G. bathoniana occurs frequently in the Morrisi Zone (middle Bathonian) of the ore-bearing Czestochowa clays in which it was originally described (Pazdrowa, 1969). Both G. bathoniana and G. balakhmatovae are known from the late Bathonian of other locations on the margins of the Tethys, namely, Grand Banks in Eastern Canada (Gradstein, 1979; Stam, 1986) and the lower Bathonian (Zigzag Zone) of central Dagestan (Morozova and Moskalenko, 1961). In general, G. bathoniana appeared slightly earlier than G. balakhmatovae and is characterized by a wider stratigraphical range (Gradstein et al., 2017b) encompassing the interval from the early Bajocian to the late Tithonian, whereas the latter appeared from the middle Bajocian to the end of the Kimmeridgian (Fig. 5). Whereas G. bathoniana was constantly recorded from the Bathonian up to the Oxfordian in the studied area, G. balakhmatovae was missing from the Callovian samples (Fig. 6).

The general stratigraphical range of $G$. oxfordiana is assessed as early Bajocian-late Tithonian - i.e. exactly the same range as that of $G$. bathoniana (Gradstein et al., 2017b). The first appearances of both taxa were established as the basis for the Jurassic planktic foraminiferal zone J2. Its lower Bajocian and Bathonian occurrence has been confirmed from, for example, Hungary (Humphriesianum and Niortense zones; Wernli and Görög, 1999) and Eastern Canada (Stam, 1986) respectively. These records challenge the hypothesis that the range of this taxon is restricted to the Oxfordian stage (Simmons et al., 1997).

In the studied area, $C$. helvetojurassica has been found only in the upper Oxfordian (Bifurcatus Zone) of Stare Gliny (Fig. 6); this is the first record of this taxa in extra-Carpathian Poland. C. helvetojurassica has been typically described from Tethyan strata, e.g. the middle Oxfordian Transversarium Zone of Switzerland (Gradstein et al., 2017a) and the lower Kimmeridgian Planula-Platynota zones of Portugal (Stam, 1986; Gradstein, 2017; Gradstein et al., 2017a) and France (Görög and Wernli, 2013). In general, C. helvetojurassica ranges from the middle Oxfordian to the early Kimmeridgian; its first appearance defines the beginning of the planktonic foraminiferal zone J5.

The co-occurrence of the four species $C$. helvetojurassica, G. balakhmatovae, G. bathoniana, and G. oxfordiana in the marls of the Stare Gliny section indicate zone J5 of Gradstein et al. (2017b) (Fig. 6). This zone, ranging from the middle Oxfordian to the early Kimmeridgian, is defined by

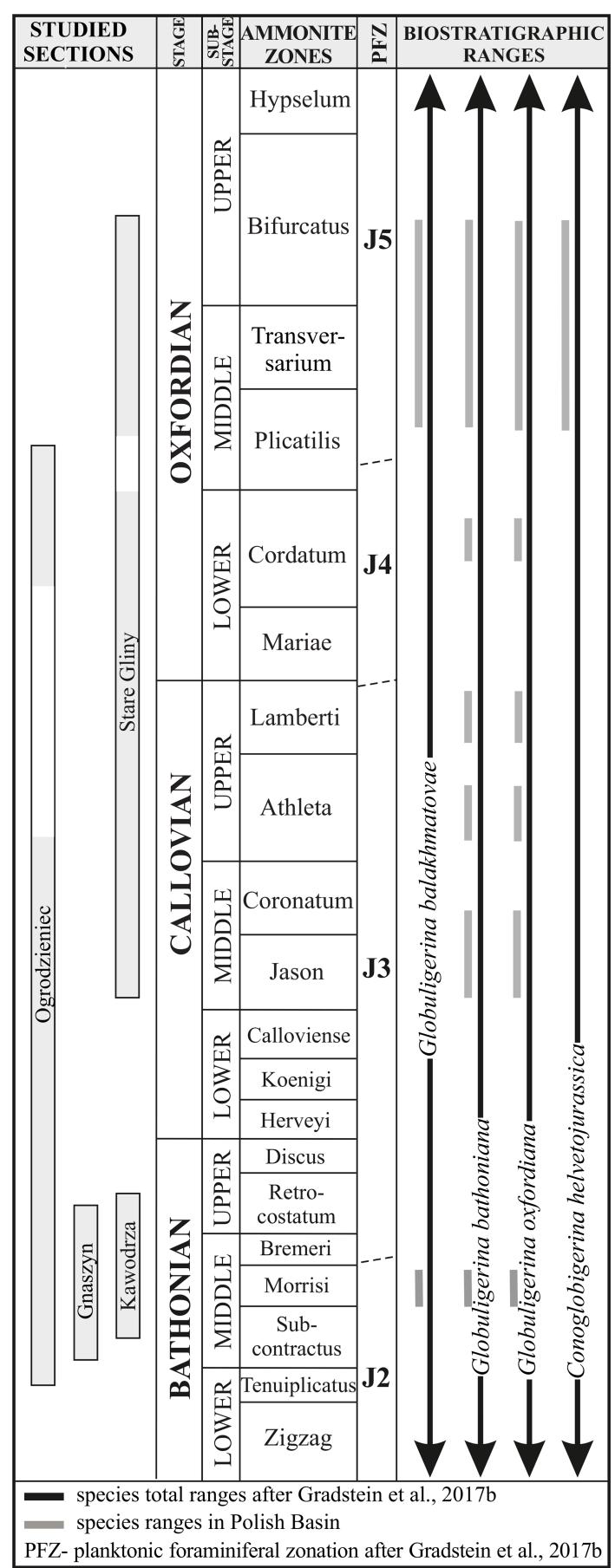

Figure 6. Chronostratigraphy, lithological columns, and ranges of recorded species of planktonic foraminifera in the studied sections, including a comparison with their total Tethyan ranges (Gradstein et al., 2017b).

the first appearance of the genus Conoglobigerina as well as the common occurrence of typical simple and hemispherical forms such as G. balakhmatovae, G. bathoniana, and G. oxfordiana. Regrettably, due to the wide stratigraphical ranges of Jurassic planktic forms and the lack of characteris- 
tic events, no other zones were identified from the remainder of the sampling material.

\subsection{Distribution of Jurassic planktonic foraminifera in extra-Carpathian Poland and their palaeoenvironmental potential}

Planktic foraminifera are undoubtedly very useful palaeoenvironmental and palaeoecological proxies due to their close relationship with test morphology (morphotype) and with the habitat they occupied. Moreover, their tests constitute a useful medium for recording stable (carbon and oxygen) isotopes or ratios of trace elements such as $\mathrm{Mg}$ and $\mathrm{Sr}$.

The geographical distribution of Holocene planktic foraminifera is restricted to fully marine habitats from the Equator to relatively high latitudes. These organisms occur in the water column from the surface water to several hundred metres in the water column (Bé and Hamlin, 1967; Bé, 1977; Schiebel and Hemleben, 2005, 2017). Thus, the union of Tethys and the proto-Atlantic with adjacent epicontinental seas during the mid-Late Jurassic apparently resulted in the expansion of planktic forms (Hart et al., 2002; Hudson et al., 2009; BouDagher-Fadel, 2015). Planktic foraminifera, having originated in the Tethys Zone, subsequently migrated into adjacent epicontinental seas, and a brief review of their development follows.

The earliest planktic foraminifera appear to be those described by Wernli (1995) from the Creux de l'ours section in the area of Teysachaux (Swiss Prealps, Fribourg, Switzerland). The mudstones from which the planktic foraminifera were recovered are located within a few metres of the Toarcian Oceanic Anoxic Event (OAE), an event recently reinterpreted by Ruebsam et al. (2019) as possibly related to warming and sea level rise following a glacial (or cold) event. In the UK, Hylton (2000) and Hart et al. (2003) recorded a flood of inflated Oberhauserella or Rheinholdella at the same stratigraphical level immediately above the Toarcian OAE (Whitby Mudstone Formation). Planktic foraminifera are rare in the overlying Aalenian (Wernli, 1988), becoming more abundant (and widespread) in the Bajocian (Gradstein et al., 2017b). Many of the mid-Jurassic occurrences are in "Ammonitico Rosso" facies in which ammonites and calcite "filaments" are the only other fossils. The important questions are as follows:

1. Are these mid-Jurassic planktic foraminifera with simple test arrangements surface-dwelling forms?

2. Do all of these Jurassic planktic foraminifera have aragonitic tests and are they, therefore, a completely unrelated lineage to most Cretaceous taxa?

3. Why are Jurassic assemblages so species-poor and why did they never developed greater diversity?

In answer to question 1, the simple "globigerine" forms, which often have only three to four chambers in the final whorl, appear comparable to many Cretaceous taxa in which stable isotope analysis (Wendler et al., 2013) indicates the occupation of surface waters (above the thermocline). In a recent study of Globuligerina spp. from Poland and Portugal, Kendall et al. (2020) - using micro computed tomography (micro-CT) analysis - suggest that this morphology reflects short life cycles and potentially rapid reproduction in nutrient-rich coastal environments.

In the Czorsztyn Limestone Formation (Oxfordian) of the Pieniny Klippen Belt of Poland, Hudson et al. (2009) described thin sections full of simple, globigerina, forms (often with a maximum of four chambers in the final whorl) and very few associated benthic taxa. These were thought to represent open-ocean environments in which a $99: 1 \mathrm{P}: \mathrm{B}$ ratio indicates planktic ooze deposition above a Jurassic aragonite compensation depth (ACD), although the actual water depth is impossible to estimate. The palaeoenvironmental evidence of Hudson et al. (2009) and Hart et al. (2012), coupled with the morphological analysis of Kendall et al. (2020), is suggestive of a surface-water dwelling habitat for most Jurassic planktic foraminifera.

These species were, therefore, able to spread into shelf seas only during sea level highstands (Gordon, 1970), which resulted in the minimum seawater depth required for these organisms to thrive. It is also believed that foraminiferal migration farther into the shelves was additionally associated with the occasional incursion of warm currents (Gordon, 1970; Riegraf, 1987; Hudson et al., 2009). Therefore, it is possible that planktic foraminifera first appeared in the Polish epicontinental seas during a transgressive interval in the late Bathonian (Morrisi Zone) (Dayczak-Calikowska and Kopik, 1973b; Leonowicz, 2016), where they were recorded (Fig. 5) in the Polish Jura (Pazdrowa, 1969; Fuchs, 1973; Smoleń, 2012) as well as in northern Poland (Bielecka and Styk, 1981). No planktic foraminifera have been recorded in the Aalenian and Bajocian, as these stages are represented by very shallow, although transgressive, facies only as the Aalenian sea entered the Polish Basin (DayczakCalikowska, 1997). Until the late Bajocian, the basin in the Polish Lowlands was very narrow (elongated in a northwestern-south-eastern direction) and had not expanded towards the north-eastern part of Poland (Dayczak-Calikowska and Kopik, 1973b). During the late Bathonian, a significant expansion took place and, as a result, the sea covered nearly all of the Polish Lowlands (Dayczak-Calikowska and Kopik, 1973b; Leonowicz, 2016). The first planktic foraminifera from the area of Poland are actually recorded from the Bathonian: G. bathoniana and G. oxfordiana (e.g. Pazdrowa, 1969; Smoleń, 2012; Hart et al., 2012; Kendall et al., 2020).

A short-term, relatively rapid, regression occurred in the early Callovian, particularly affecting the basin in the Polish Lowlands (Dayczak-Calikowska and Kopik, 1973b); G. bathoniana and G. oxfordiana have rarely been recorded subsequently, even in the southern parts of the Polish Basin (Bielecka and Styk, 1967; Bielecka, 1960; Bielecka and 
Styk, 1981). Similarly, as in their early Callovian distribution, both species occurred sporadically in the middle and upper Callovian samples from Stare Gliny and Ogrodzieniec. Contrastingly, during the late Callovian-Oxfordian interval, planktic foraminifera expanded to attain their widest distribution, described as the "foraminiferal flood" across Europe (Hudson et al., 2009), which was apparently connected with global oceanographical and climatic changes occurring at the transition between the Middle and Upper Jurassic (Callovian to Oxfordian). Specifically, a marked transgression, beginning in the late Callovian and continuing until the Kimmeridgian (Dadlez et al., 1998), resulted in the appearance of widespread epicontinental seas, which communicated with the Tethys covering much of Europe, as well as in climate warming. Mediterranean ammonites began to be found instead of boreal taxa in the Oxfordian strata of the Polish Jura (Dąbrowska, 1973), and this was simultaneous with with the first occurrence of typical Tethyan foraminifera (C. helvetojurassica and $G$. balakhmatovae) which were recorded in our studies in the Oxfordian of Stare Gliny. In general, in the Oxfordian, planktic foraminifera (G. oxfordiana) expanded to the northern margins of the Polish Basin (Fig. 5; Bielecka, 1974; Bielecka and Styk, 1964, 1966, 1981), as well as in the Lithuanian and Russian basins (Grigelis, 1958, 1977; Grigelis, 2016; Gradstein et al., 2017a). Excellently preserved G. oxfordiana specimens are recorded from lower Oxfordian dark clay- and siltstones of Lithuanian boreholes (Grigelis, 1958) and middle to late Oxfordian strata of central Russia (Grigelis, 1977; Gradstein et al., 2017a). The abundance of planktonic foraminifera in the Russian Sea (Makar'yev section, Volga River Basin, Russia) during the middle Oxfordian is related to palaeogeographical changes, such as sea level highstands associated with the opening of the pathway connecting the northern Tethys with the Boreal realm (Colpaert et al., 2016). Moreover, it was in the Oxfordian that planktic foraminifera expanded northwards; G. oxfordiana has been recorded from lower Oxfordian strata of Sweden (Gorbachik and Kuznetsova, 1983).

The depth distribution and variability of Holocene planktic foraminifera is related to morphology (Bé and Hamlin, 1967; Bé, 1977; Schiebel and Hemleben, 2005, 2017), and this relationship has been used in the interpretation of habitats of ancient morphotypes. The connection between the life cycle of planktic foraminifera and depth stratification is expressed as a depth-morphogroup model commonly applied to Cretaceous (Hart and Bailey 1979; Hart, 1980; Caron and Homewood 1983; Leckie, 1987) and Cenozoic (Keller, 1985) palaeoenvironmental interpretations. According to this general model, the simple, small globigerina-like morphotypes of the Cretaceous lived near the surface of the water, while more complex, larger, hemispherical- or keel-chambered morphotypes preferred deeper to intermediate habitats. Unfortunately, no depth-morphogroup model has been proposed for Jurassic taxa. Jurassic foraminifers are probably a separate lineage than Cretaceous-Holocene foraminifera in possessing aragonite instead of calcite shells. The only lineage that appears to cross the Jurassic-Cretaceous boundary is that which includes the favusellids, and this genus extends, in relative low numbers, up into the mid-Cenomanian, with the last species being Favusella washitensis (Carsey, 1926). There are no other lineages that appear to develop from the favusellids. However, when we analysed the distribution of the Jurassic planktonic foraminifera in the Polish Lowlands in relation to the sea level curve as well as to facies distribution and the palaeogeographical map (distance from the ocean) (Hudson et al., 2009; Wierzbowski et al., 2009; Leonowicz, 2016), the depth-distribution pattern of Jurassic planktonic foraminifera appeared comparable to that of the Cretaceous. Specifically, the shallow shelf facies and the areas quite distant from the open ocean yielded only small, simple morphotypes such as G. bathoniana and G. oxfordiana. Planktic foraminiferal assemblages composed of only these two morphologically simple forms have been collected mostly from the Bathonian and Callovian, as these strata were deposited in a still relatively shallow sea. Only monospecific G. oxfordiana planktonic assemblages have been recorded in the Oxfordian strata of the northern part of the Polish Basin, implying that, in the Oxfordian, the northern margin of the basin was invaded by only shallow-dwelling forms, in contrast to the southernmost part of the basin, which represented a deeper-shelf environment, where planktic foraminiferal assemblages were slightly more diverse and represented by more complex and larger forms, such as $G$. balakhmatovae and $C$. helvetojurassica. This is suggestive of a deepening of the environment towards the outer shelf and open ocean. To summarize, assemblages composed of only simple forms such as G. bathoniana and G. oxfordiana were typical of rather shallow- and midshelf environments, and, by analogy to Holocene counterparts, may have been characterized by short life cycles which may have unfolded in relatively shallow waters beyond the open ocean. The Oxfordian of the Stare Gliny outcrop, deposited in an outer-shelf environment, closer to the Tethys (actually, Stare Gliny represents the southernmost available Jurassic strata of the Polish epicontinental basin), contains more diverse planktic assemblages. In addition to simple G. bathoniana and G. oxfordiana, it contains hemispherical G. balakhmatovae and the larger morphotype $C$. helvetojurassica. The latter was the most evolutionarily advanced species of all those reported in this study and may have needed a much greater water column to establish favourable conditions for its life cycle. 


\section{Conclusions}

Four species of Jurassic planktonic foraminifera, Conoglobigerina helvetojurassica (Haeusler, 1881), Globuligerina balakhmatovae (Morozova, 1961), Globuligerina bathoniana (Pazdrowa, 1969), and Globuligerina oxfordiana (Grigelis, 1958), were identified in material from extra-Carpathian Poland. In general, the level of richness of the studied assemblages was rather low and undifferentiated. The majority were represented by only two common taxa, G. bathoniana and G. oxfordiana. Nevertheless, an assemblage from the middle-upper Oxfordian clays and marls of the Stare Gliny Quarry includes all four of the species mentioned above, making it currently the most diverse planktic foraminiferal assemblage of the European epicontinental Jurassic.

The stratigraphical distributions of all of the studied taxa closely match the general biostratigraphical zonation for Jurassic planktic foraminifera (Gradstein et al., 2017b). The first planktic foraminifera from the Polish Basin, G. bathoniana and G. balakhmatovae, derive from middle Bathonian (Morrisi Zone) transgressive deposits of the Polish Jura. In the middle-upper Callovian (Jason-Lamberti zones) of the Polish Jura, planktic foraminifera, represented by G. bathoniana and G. oxfordiana, are discontinuously and rather sparsely recorded. Due to the late Callovian-Oxfordian transgression, planktic foraminifera migrated to the northern part of the Polish area, where they are represented mostly by monospecific assemblages of $G$. oxfordiana, in contrast to the southern part, where assemblages are more diverse and contain complex Tethyan forms.

Three separate test morphotypes within the studied Jurassic planktic foraminifera were distinguished: a small and simple globular-chambered morphotype represented by G. bathoniana (the mean diameter of all the studied specimens is ca. $160 \mu \mathrm{m}$ ) and $G$. oxfordiana (the mean diameter of the studied specimens is ca. $150 \mu \mathrm{m}$ ), a hemispherically chambered morphotype by G. balakhmatovae, and a large and complex morphotype by $C$. helvetojurassica (the mean diameter of all the studied specimens is ca. $260 \mu \mathrm{m}$ ). These morphotypes apparently reflect the close relationship between the settled habitat and test morphology. The deeper the environment, the more diverse the foraminiferal assemblages that occurred there, with a significant share of large and complex forms. Contrastingly, small and simple foraminifera dominated the shallow inner-shelf environments. This distribution pattern would have some similarities to depth-distribution models created for younger forms such as Late Cretaceous planktic foraminifera (Leckie, 1987; Caron and Homewood, 1983). Thus, beyond doubt, Jurassic planktic foraminifera may also be regarded as useful depth indicators for palaeoenvironmental studies.

In general, our studies provide new insight into the palaeoecology, evolution, and distribution of Jurassic planktic foraminifera from the Polish Jura. However, the group still requires more investigation.
Author contributions. ZD conceived this research project. MG processed and analysed the samples. All authors interpreted results and wrote and edited the article.

Competing interests. Malcolm B. Hart reviewed the first version of this paper and suggested substantive improvements. He then participated as a co-author when the paper was revised.

Acknowledgements. We kindly thank Krzyś Dembicz for his invaluable help during fieldwork. Christopher W. Smart (University of Plymouth) generated Figs 1 and 2 from the SEM micrographs. Jarosław Tyszka and Eiichi Setoyama assisted with the fieldwork in 2011. Holger Gebhardt (Geological Survey of Austria) is thanked for providing access and microscope facilities for work on the collections of Rudolf Oberhauser and Werner Fuchs.

Financial support. This research has been supported by the National Science Centre, Poland (grant no. UMO2017/27/B/ST10/00687).

Review statement. This paper was edited by Laia Alegret and reviewed by Malcolm B. Hart, Mike Simmons, and one anonymous referee.

\section{References}

Apthorpe, M.: Middle Jurassic (Bajocian) planktonic foraminifera from the northwest Australian margin, J. Micropalaeontol., 39, 93-115, https://doi.org/10.5194/jm-39-93-2020, 2020.

Barski, M., Dembicz, K., and Praszkier, T.: Biostratigraphy and the Mid-Jurassic environment from the Ogrodzieniec quarry, Tomy Jurajskie, 2, 61-68, 2004.

Bé, A. W. H.: An ecological, zoogeographic and taxonomic review of recent planktonic foraminifera, in: Oceanic Micropaleontology, edited by: Ramsey, A. T. S., Academic Press, London, 76$88,1977$.

Bé, A. W. H. and Hamlin, W. H.: Ecology of recent planktonic forminifera, Part III. Distribution in the North Atlantic during the summer of 196, Micropaleontology, 13, 87-106, 1967.

Bielecka, W.: Stratygrafia mikropaleontologiczna dolnego malmu okolic Krakowa, Prace Instytutu Geologicznego, 31, 60-78, 1960.

Bielecka, W.: Wyniki badań mikrofaunistycznych jury środkowej i górnej, in: Profile Głębokich Otworów Wiertniczych Instytutu Geologicznego: Bartoszyce IG1, Gołdap IG1, edited by: Modliński, Z., Instytut Geologiczny, Wydawnictwa Geologiczne, Warszawa, 14, 171-180, 1974.

Bielecka, W. and Styk, O.: Stratygrafia mikropaleontologiczna jury górnej w wierceniu Kcynia I, II, III, Biul. Państw. Instyt. Geol., 175, 129-152, 1964.

Bielecka, W. and Styk, O.: Mikrofauna malmu południowej części syneklizy perybałtyckiej, Kwartalnik Geologiczny, 10, 350-367, 1966. 
Bielecka, W. and Styk, O.: The Callovian and Oxfordian in the vicinity of Ogrodzieniec, Biul. Państw. Instyt. Geol., 211, 128146, 1967.

Bielecka, W. and Styk, O.: Biostratygrafia batonu i keloweju północno-zachodniej Polski na podstawie otwornic i małżoraczków, Pr. Inst. Geol., 100, 5-56, 1981.

BouDagher-Fadel, M. K.: The Mesozoic planktonic foraminifera: The Late Triassic-Jurassic, in: Biostratigraphic and Geological Significance of Planktonic Foraminifera, UCL Press, London, 39-60, https://doi.org/10.2307/j.ctt1g69xwk.6, 2015.

Carron, M. and Homewood, P.: Evolution of early planktic foraminifers, Mar. Micropaleontol., 7, 453-462, https://doi.org/10.1016/0377-8398(83)90010-5, 1983.

Carsey, D. O.: Foraminifera of the Cretaceous of central Texas, University of Texas Bulletin, 2612, 1-56, 1926.

Colpaert, C., Nikitenko, B., Khafaeva, S., and Wall, A. F.: The evolution of Late Callovian to Early Kimmeridgian foraminiferal associations from the central part of the Russian Sea (Makar'yev section, Volga River Basin, Russia), Palaeogeogr. Palaeocl., 451, 97-109, https://doi.org/10.1016/j.palaeo.2016.03.014, 2016.

Dąbrowska, Z.: Paleogeografia, Obszar pozakarpacki, Jura górna, in: Budowa Geologiczna Polski, Stratygrafia, Cz. 2., Mezozoik, Wydawnictwa Geologiczne, Warszawa, 453-461, 1973.

Dadlez, R., Marek, S., and Pokorski, J.: Paleozoogeographical Atlas of the Epicontinental Permian and Mesozoic in Poland, Pol. Geol. Inst., Warszawa, 82 pp., 1998.

Dayczak-Calikowska, K.: Middle Jurassic: Sedimentation, palaeogeography and palaeotectonics, Pr. Panstw. Inst. Geol., 153, 269282, 1997

Dayczak-Calikowska, K. and Kopik, J.: Obszary występowania i stratygrafia, Jura środkowa, Wyżyna Krakowsko-Wieluńska, in: Budowa Geologiczna Polski, Stratygrafia, Cz. 2., Mezozoik, Wydawnictwa Geologiczne, Warszawa, 237-249, 1973a.

Dayczak-Calikowska, K. and Kopik, J.: Paleografia, Obszar pozakarpacki, Jura środkowa, in: Budowa Geologiczna Polski, Stratygrafia, Cz. 2., Mezozoik, Wydawnictwa Geologiczne, Warszawa, 444-452, 1973b.

Dembicz, K. and Praszkier, T.: Zróżnicowanie litofacjalne osadów keloweju w rejonie Zawiercia, Volumina Jurassica, 1, 49-52, 2003.

Dembicz, K., Głowniak, E., Matyja, B., and Praszkier, T.: Stop B1.4 - Ogrodzieniec Quarry, uppermost Bathonian to Middle Oxfordian ammonite succession, in: Jurassic of Poland and adjacent Slovakian Carpathians, Field trip guidebook of 7th International Congress on the Jurassic System Poland, edited by: Wierzbowski, A., Aubrecht, R., Golonka, J., Gutowski, J., Krobicki, M., Matyja, B. A., Pieńkowski, G., and Uchman, A., Pol. Geol. Inst., Warszawa, 144-148, 2006.

Fuchs, W.: Über Ursprung und Phylogenie de Trias-"Globigerinen" und die Bedeutung Dieses Formenkreises für das echte Plankton, Ver. Geol. Bundesanst., Wien, 135-176, 1967.

Fuchs, W.: Eine alpine, tiefliassische Foraminiferenfauna von Hernstein in Niederösterreich, Verhandlungen der Geologischen Bundesanstalt, 66-145, 1970.

Fuchs, W.: Ein Beitrag zur Kenntnis der Jura-"Globigerinen" und verwandter Formen an Hand polnischen Materials des Callovien und Oxfordien, Verhandlungen der Geologischen Bundesanstalt, 3, 445-487, 1973.
Giżejewska, M. and Wieczorek, J.: Remarks on the Callovian and Lower Oxfordian of the Zalas area (Cracow Upland, Southern Poland), Bulletin de l'Acade'mie Polonaise des Sciences, Se'rie Sciences des Sciences de la Terre, 24, 167-175, 1977.

Głowniak, E.: The perisphinctid genus Prososphinctes (Ammonoidea, subfamily Prososphinctinae): an indicator of palaeoecological chnages in the Early Oxfordian Submediterranean sea of southern Poland, N. Jb. Geol. Paläont. Abh., 264, 117-179, https://doi.org/10.1127/0077-7749/2012/0235, 2012.

Gorbachik, T. N. and Kuznetsova, K. I.: Jurassic and Early Cretaceous planktonic foraminifera (Favusellidae), Stratigraphy and paleobiogeography, Zitteliana, 10, 459-466, 1983.

Gordon, W. A.: Biogeography of Jurassic Foraminifera, GSA Bulletin, 81, 1689-1704, 1970.

Görög, A.: Early Jurassic planktonic foraminifera from Hungary, Micropaleontology, 40, 255-260, https://doi.org/10.2307/1485819, 1994.

Görög, A. and Wernli, R.: Protoglobigerinids of the Early Kimmeridgian of the Jura Mountains (France), J. Foramin. Res., 43, 280-290, 2013.

Gradstein, F.: Jurassic foraminifera of the Grand Banks, Ciencias da Terra, 5, 85-96, 1979.

Gradstein, F. M.: New and emended species of Jurassic planktonic foraminifera, Swiss J. Palaeontol., 136, 161-185, https://doi.org/10.1007/s13358-017-0127-8, 2017.

Gradstein, F., Gale, A., Kopaevich, L., Waskowska, A., Grigelis, A., and Glinskikh, L.: The planktonic foraminifera of the Jurassic, Part I: Material and taxonomy, Swiss J. Palaeontol., 136, 187257, 2017a.

Gradstein, F., Gale, A., Kopaevich, L., Waskowska, A., Grigelis, A., Glinskikh, L., and Görög, Á.: The planktonic foraminifera of the Jurassic, Part II: Stratigraphy, palaeoecology and palaeobiogeography, Swiss J. Palaeontol., 136, 259-271, $2017 \mathrm{~b}$.

Grigelis, A. A.: Globigerina oxfordiana sp. n. - an occurrence of Globigerina in the Upper Jurassic deposits of Lithuania, Nauchnyye Doklady Vysshey Shkoly, Geol.-Geogr. Nauki, 1958, 109$111,1958$.

Grigelis, A. A., Mesezhnikov, M. S., Yakovleva, S. P., and Kozlova, G. E.: The first finds of planktonic foraminifers in the Upper Jurassic of the Pechora river basin, Dokl. Akad. Nauk SSSR, 233, 926-927, 1977.

Grigelis, A.: Globuligerina oxfordiana (Grigelis, 1958) - revision of the first planktonic foraminifera discovered in the Upper Jurassic of Lithuania, Geologija Geografija, 2, 62-83, 2016.

Hart, M. B.: A water depth model for the evolution of the planktonic Foraminiferida, Nature, 286, 252-254, 1980.

Hart, M. B.: The evolution and biodiversity of Cretaceous planktonic Foraminiferida, Geobios, 32, 247-255, 1999.

Hart, M. B. and Bailey, H. W.: The distribution of planktonic Foraminiferida in the mid-Cretaceous of NW Europe, Aspekte der Kreide Europas, IUGS, Series A, 6, 527-542, 1979.

Hart, M. B., Hudson, W., Smart, C. W., and Tyszka, J.: A reassessment of "Globigerina bathoniana" Pazdrowa, 1969 and the palaeoceanographic significance of Jurassic planktic foraminifera from southern Poland, J. Micropalaeontol., 31, 97109, https://doi.org/10.1144/0262-821X11-015, 2012.

Hart, M. B., Hylton, M. D., Oxford, M. J., Price, G. D., Hudson, W., and Smart, C. W.: The search for the origin 
of the planktic Foraminifera, J. Geol. Soc., 160, 341-343, https://doi.org/10.1144/0016-764903-003, 2003.

Hart, M. B., Oxford, M. J., and Hudson, W.: The early evolution and palaeobiogeography of Mesozoic planktonic foraminifera, in: Palaeobiogeography and biodiversity change: the Ordovician and Mesozoic-Cenozoic radiations, edited by: Crame, J. A. and Owen, A. W., Geological Society, London, Special Publications, 194, 115-125, 2002.

Hart, M. B., Page, K. N., Price, G. D., and Smart, C. W.: Reconstructing the Christian Malford ecosystem in the Oxford Clay Formation (Callovian, Jurassic) of Wiltshire: exceptional preservation, taphonomy, burial and compaction, J. Micropalaeont., 38, 133-142, 2019.

Haeusler, R.: Untersuchungen ueber die microscopischen Structurverhaeltnisse der Aargauer Jurakalke, mit besonderes Beruecksichtigung iherer Foraminiferenfauna, Dissertation, University of Zurich, 47 pp., 1881.

Hudson, W.: The evolution and palaeobiogeography of Mesozoic planktonic foraminifera, Unpublished PhD Thesis, University of Plymouth, 541 pp., 2007.

Hudson, W., Hart, M. B., and Smart, C. W.: Palaeobiogeography of early planktonic foraminifera, Bull. Soc. Géol. Fr., 180, 27-38, 2009.

Hylton, M. D.: Microfaunal investigation of the Early Toarcian (Lower Jurassic) extinction event in N. W. Europe, Unpublished PhD Thesis, University of Plymouth, 331 pp., 2000.

Jurkowska, A. and Kołodziej, B.: Taphonomic differentiation of Oxfordian ammonites from the Cracow Upland, Poland, Paleontol Z., 87, 67-82, https://doi.org/10.1007/s12542-012-0149-x, 2013.

Keller, G.: Depth stratification of planktonic foraminifers in the Miocene Ocean, GSA Memoir., 163, 177-195, 1985.

Kendall, S., Gradstein, F., Jones, C., Lord, O. T., and Schmid, D. N.: Ontogenetic disparity in early planktic foraminifers, J. Micropalaeontol., 39, 27-39, 2020.

Leckie, R. M.: A paleoceanographic model for the early evolutionary history of planktonic foraminifera, Palaeogeogr. Palaeocl., 73, 107-138, 1987.

Leckie, R. M.: Seeking a better life in the plankton, P. Natl. Acad. Sci. USA, 106, 14183-14184, https://doi.org/10.1073/pnas.0907091106, 2009.

Leonowicz, P.: Sedimentology and ichnology of Bathonian (Middle Jurassic) ore-bearing clays at Gnaszyn, KrakówSilesia Homocline, Poland, Acta Geol. Pol., 62, 281-296, https://doi.org/10.2478/v10263-012-0015-x, 2012.

Leonowicz, P.: The significance of mudstone fabric combined with palaeoecological evidence in determining sedimentary processes - an example from the Middle Jurassic of southern Poland, Geol. Q., 57, 243-260, https://doi.org/10.7306/gq.1092, 2013.

Leonowicz, P.: Nearshore transgressive black shale from the Middle Jurassic shallow-marine succession from southern Poland, Facies, 62, 1-23, https://doi.org/10.1007/s10347-016-0467-7, 2016.

Loeblich, A. R. and Tappan, H.: Foraminiferal genera and their classification, van Nostrand Reinhold, Hew York, 2 Volumes, 695714, 1987.

Masters, B. A.: Mesozoic planktonic Foraminifera, in: Oceanic Micropalaeontology, edited by: Ramsay, A. T. S., Academic Press, London, 1, 301-731, 1977.
Matyja, B. and Głowniak, E.: Następstwo amonitów dolnego i środkowego oksfordu w profilu kamieniołomu w Ogrodzieńcu i ich znaczenie biogeograficzne, Volumina Jurassica, 1, 53-58, 2003.

Matyja, B. and Wierzbowski, A.: Biostratygrafia amonitowa formacji częstochowskich iłów rudonośnych (najwyższy bajos-górny baton) z odsłonięć w Chęstochowie, Volumina Jurassica, 1, 3-6, 2003.

Matyja, B. and Wierzbowski, A.: Field Trip B1 - Biostratigraphical framework from Bajocian - Oxfordian, in: Jurassic of Poland and adjacent Slovakian Carpathians, edited by: Wierzbowski, A., Aubrecht, R., Golonka, J., Gutowski, J., Krobicki, M., Matyja, B. A., Pieńkowski, G., and Uchman, A., Field Trip Guidebook of the 7th International Symposium on the Jurassic System, 133168, 2006.

Matyja, B., Dembicz, K., and Praszkier, T.: Stop B1.8 - Wrzosowa Quarry, condensed Callovian and Lower Oxfordian ammonite succession, in: Jurassic of Poland and adjacent Slovakian Carpathians, Field trip guidebook of 7th International Congress on the Jurassic System Poland, edited by: Wierzbowski, A., Aubrecht, R., Golonka, J., Gutowski, J., Krobicki, M., Matyja, B. A., Pieńkowski, G., and Uchman, A., Pol. Geol. Inst., Warszawa, 157-160, 2006a.

Matyja, B., Wierzbowski, A., Gedl. P., Boczarowski, A., Dudek, T., Kaim, A., Kędzierski, M., Leonowicz, P., Smoleń, J., Szczepanik, P., Witkowska, M., Ziaja, J., and Ostrowski, S.: Stop B1.7 - Gnaszyn clay pit (Middle Bathonian-lowermost Upper Bathonian), in: Jurassic of Poland and adjacent Slovakian Carpathians, Field trip guidebook of 7th International Congress on the Jurassic System Poland, edited by: Wierzbowski, A., Aubrecht, R., Golonka, J., Gutowski, J., Krobicki, M., Matyja, B. A., Pieńkowski, G., and Uchman, A., Pol. Geol. Inst., Warszawa, 154-156, 2006b.

Morozova, V. G. and Moskalenko, T. A.: Foraminiferes planctoniques des depots limitrophes du Bajocien et du Bathonien du Daghestan central (Nord-Est du Caucase), Voprosy Mikropaleontologii, 5, 3-30, 1961.

Oberhauser, R.: Foraminiferen und Mikrofossilien "incertae sedis" der Ladinischen und Karnischen Stufe der Trias aus den Ostalpen und aus Persien, in: Beiträge zur Mikropaläontologie der Alpinen Trias, edited by: Oberhauser, R., Kristan-Tollmann, Kollman, K., and Klaus, W., Jb. Geol. Bundesanst., Wien, Special, 5, 5-46, 1960.

Ogg , J. G., Ogg, G. M., and Gradstein, F.: A concise geologic time scale 2016, Cambridge, Elsevier, 240 pp., 2016.

Olszewska, B. and Wieczorek, J.: Callovian-Oxfordian foraminifera from the Northern Tethyan Shelf: An example from the Cracow Upland (Southern Poland), Revue de Paléobiologie, 2, 191-196, 1988.

Parent, H. and Zatoń, M.: Sexual dimorphism in the Bathonian morphoceratid ammonite Polysphinctites tenuiplicatus, Acta Palaeontol. Pol., 61, 4, 875-884, https://doi.org/10.4202/app.00261.2016, 2016.

Pawlowski, J., Holzmann, M., Berney, C., Fahrni, J., Gooday, A. J., Cedhagen, T., Habura, A., and Bowser, S. S.: The evolution of early Foraminifera, P. Natl. Acad. Sci. USA, 100, 11494-11498, https://doi.org/10.1073/pnas.2035132100, 2003.

Pazdrowa, O.: Bathonian Globigerina of Poland, Rocznik Polskiego Towarzystwa Geologicznego, 39, 41-56, 1969. 
Premoli Silva, I. and Sliter, W. V.: Cretaceous paleoceanography: evidence from planktonic foraminiferal evolution, Geol. Soc. Am., Special Paper, 332, 301-328, 1999.

Remin, Z., Dubicka, Z., Kozłowska, A., and Kuchta, B.: A new method of rock disintegration and foraminiferal extraction with the use of liquid nitrogen, Mar. Micropaleontol., 86, 11-14, https://doi.org/10.1016/j.marmicro.2011.12.001, 2012.

Riegraf, W.: Planktonic Foraminifera (Globuligerinidae) from the Callovian (Middle Jurassic) of Southwest Germany, J. Foraminiferal Res., 17, 190-211, 1987.

Różycki, S.: Górny dogger i dolny malm Jury KrakowskoCzęstochowskiej, Opis odsłonięć, Prace Instytutu Geologicznego, 17, 250-259, 1953.

Ruebsam, W., Mayer, B., and Schwark, L.: Cryosphere carbon dynamics control early Toarcian global warming and sea level evolution, Global Planet. Change, 172, 440-453, 2019.

Salata, D.: Heavy minerals as detritus provenance indicators for the Jurassic pre-Callovian palaeokarst infill from the Czatkowice Quarry (Kraków-Wieluń Upland, Poland), Geol. Q., 57, 537550, 2013.

Schiebel, R. and Hemleben, C.: Modern planktonic foraminifera, Palaontol. Z., 79, 135-148, https://doi.org/10.1007/BF03021758, 2005.

Schiebel, R. and Hemleben, C.: Planktonic foraminifers in the modern oceans, Springer, Berlin, Heidelberg, Germany, 358 pp., https://doi.org/10.1007/978-3-662-50297-6, 2017.

Simmons, M. D., BouDagher-Fadel, M. K., Banner, F. T., and Whittaker, J. E.: The Jurassic Favusellacea, the earliest Globigerinina, in: Early Evolutionary History of Planktonicm Foraminifera, edited by: BouDagher-Fadel, M. K., Banner, F. T., and Whittaker, J. E., British Micropalaeontological Society Publication Series, Chapman and Hall Publishers, London, 17-50, 1997.

Smoleń, J.: Faunal dynamics of foraminiferal assemblages in the Bathonian (Middle Jurassic) ore-bearing clays at Gnaszyn, Kraków-Silesia Homocline, Poland, Acta Geol. Pol., 62, 403419, https://doi.org/10.2478/v10263-012-0023-x, 2012.

Stam, B.: Quantitative analysis of Middle and Late Jurassic foraminifera from Portugal and its implications for the Grand Banks of Newfoundland, Utrecht Micropaleontological Bulletins, 34, 1-168, 1986.
Trammer, J.: Biohermy gąbkowe warstw jasnogórskich (oksford Jury Polskiej), Przeglad Geol., 33, 78-81, 1985.

von Hillebrandt, A.: Are the Late Triassic to Early Jurassic aragonitic Oberhauserellidae (Robertinina) the ancestors of planktonic Foraminifera?, N. Jb. Geol. Paläont. Abh., 266, 199-215, https://doi.org/10.1127/0077-7749/2012/0279, 2012.

Wendler, I., Brian, H. T., MacLeod, K. G., and Wendler, J. E.: Stable oxygen and carbon isotope systematics of exquisitely preserved Turonian foraminifera from Tanzania - understanding isotopic signatures in fossils, Mar. Micropaleontol., 102, 1-33, 2013.

Wernli, R.: Les protoglobige'rines (foraminiferes) du Toarcien et de l'Aale'nien du Domuz Dag (Taurus occidental, Turquie), Eclogae geologicae Helvetiae, 81, 661-668, 1988.

Wernli, R.: Les Foraminifères globigériniformes (Oberhauserellidae) du Toarcien Inférieur de Teysachaux (Préalpes médianes, Fribourg, Suisse), Rev. Paléobiologie, 14, 257-269, 1995.

Wernli, R. and Görög, A.: Protoglobigerinids (Foraminifera) acid extracted from Bajocian limestones (Hungary), Rev. Esp. Micropaleontol., 31, 3, 419-426, 1999.

Wernli, R. and Görög, A.: Determination of Bajocian protoglobigerinids (Foraminifera) in thin sections, Rev. Paléobiologie, 19, 399-407, 2000.

Wierzbowski, A., Matyja, B., Gajewska, M., Dubicka, Z., and Barski, M.: The Middle/Upper Callovian to Oxfordian deepwater marly succesion at Stare Gliny Quarry, Polish Jura Area, Southern Poland: Ammonite stratigraphy, microfossil (Dinoflagellate cysts and Foraminifers) assemblages and paleogeographical-paleotectonical implications - in preparation, 2021.

Wierzbowski, H., Dembicz, K., and Praszkier, T.: Oxygen and carbon isotope composition of Callovian-Lower Oxfordian (Middle-Upper Jurassic) belemnite rostra from central Poland: A record of a Late Callovian global sea-level rise? Palaeogeogr. Palaeocl., 283, 182-194, https://doi.org/10.1016/j.palaeo.2009.09.020, 2009.

Witwicka, E., Bielecka, W., Styk, O., and Sztejn, J.: Metody opracowywania mikroskamieniałości, Biul. Państw. Instyt. Geol., 134, 5-156, 1958. 